\title{
Cytological Investigations in Some Indian Compositae
}

\author{
P. K. Gupta ${ }^{1}$ \\ Botany Department, Gorakhpur University, Gorakhpur, India
}

Received September 2, 1968

\section{Introduction}

Compositae is one of the biggest families of flowering plants representing about one tenth of the total number of flowering plants. The family has 800 genera and 14,000 species, sub-divided in 13 different tribes (Bentham 1873, Hooker 1882, Rendel 1959 and Hutchinson 1959). Although the family is represented in India by large number of genera and species, we still lack much knowledge regarding their chromosome constitution and behaviour. The only cytological investigations on the members of this family in this sub-continent were those by Ganesan (1939) ; Raghavan and Venkatasubban (1941), Mitra (1947), Kishore (1951), Singh (1951), Khoshoo and Sobti (1958), Shetty (1964), Mehra et al. (1965), and Kaul $(1964,1965)$. The important publications on the chromosomal studies of Compositae of New World are those of Stebbins et al. (1953), Raven et al. (1960, 1961), Ornduff et al. (1963) and of Turner and his coworkers (1959-66).

Of these studies the only comprehensive study on Indian Compositae covering 63 genera and 134 species was that of Mehra et al. (1965). This study covered the regions of Punjab Plains, Mussorie and Simla Hills in the Western Himalayas and Darjeeling Hills in the Eastern Himalayas. An attempt has been made to investigate the chromosomal complement and behaviour of certain compositae available locally at Gorakhpur, which is situated in Eastern U.P. A total number of 21 taxa belonging to 16 genera and 17 species have been studied cytologically. Only meiosis has been studied and no attempt was made to study mitotic chromosomes.

\section{Material and methods}

Flower buds were collected from the fields in case of wild species or from the Gardens in case of cultivated ones. These were fixed immediately in Carnoy's fluid $(6: 3: 1)$. Anthers were dissected out and squashed in acetocarmine, which gave good preparations for study. Temporary preparations could be retained for some time in the medium glycerine: $45 \%$ acetic acid $(1: 10)$. Camera lucida drawings were made invariably from the temporary preparations.

Plants were identified at Central National Herbarium, Indian Botanic Gardens, Shibpur, Howrah. Voucher specimens were deposited at the

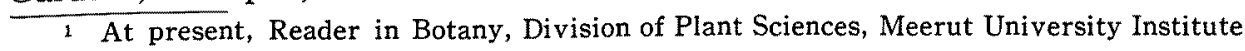
of Advanced Studies, Meerut, India. 
Herbarium of Botany Department, Gorakhpur University, Gorakhpur. For description of results the tribes have been arranged according to Hooker: Flora of British India (Vol. III, 1883).

\section{Observations}

The gametic chromosome numbers as worked out from meiosis are listed Table 1. Chromosome numbers in some North Indian Compositae

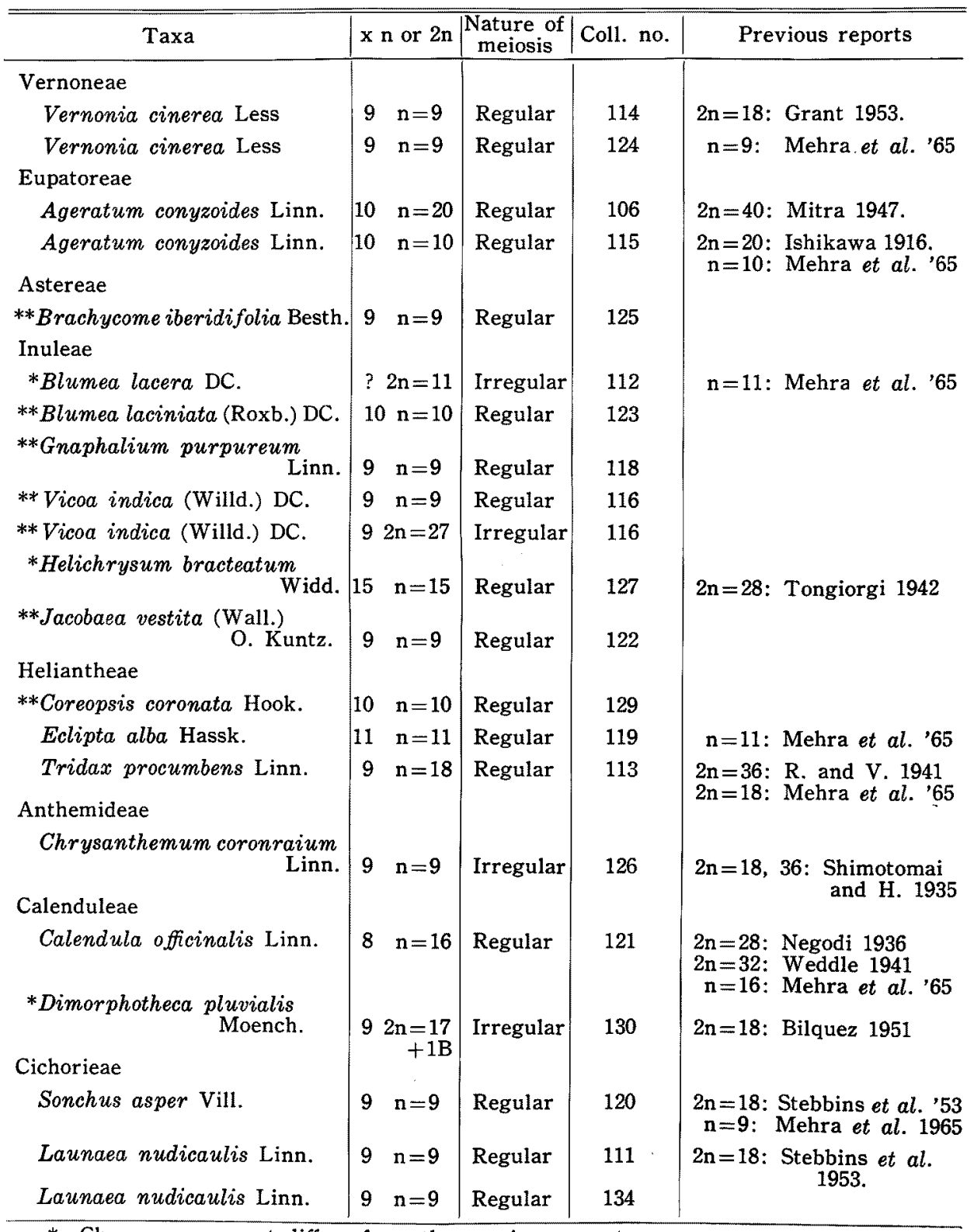

* Chromosome count differs from the previous reports.

** Species studied for the first time. 
in Table 1. In cases where the plants were not true diploids the somatic chromosome numbers have been given instead. Results of only those taxa showing relatively irregular meiosis are given in Tables 2 and 3 . The morphological variations among the ecotypes or the chromosome races found within the species are presented in Table 4. Brief account of each of the different taxa studied is being given here.

\section{Vernonia cinerea Less}

This species showed great morphological variations. Two distinct morphological types were cytologically examined. Both showed 9 bivalents at metaphase I (Fig. 1). These 2 represent ecotypes whose morphological characters are summarised in Table 4.

\section{Ageratum conyzoides Linn.}

This is quite a variable species and shows great variations in the size of the plant as well as in the size and color of the heads. Two chromosome races were studied : tetraploid and diploid. The tetraploids have greater range of morphological variations. The plants were smaller, heads were less conspicuous showing a range of color from white to purple. At diakinesis 20 bivalents were observed (Fig. 2), which regularly disjoined at anaphase I. The diploids on the other hand were more common and had purple heads. These were taller comparatively. At meiosis 10 bivalents were normally observed (Fig. 3). Morphological characters of 2 races are tabulated in Table 4.

Brachycome iberidifolia Besth.

It is a cultivated ornamental. Plants were small with an
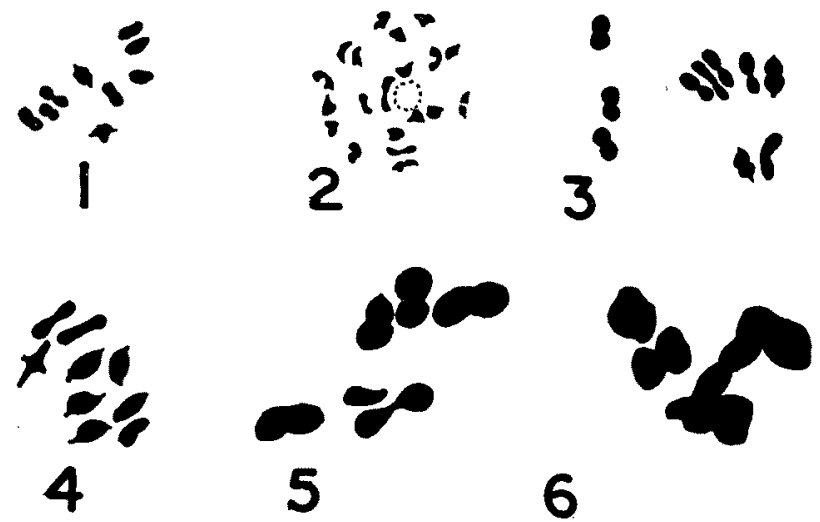

4

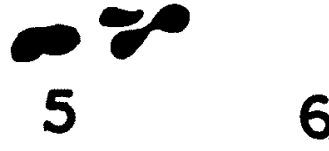

6

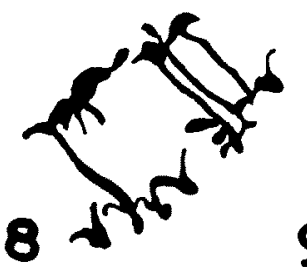

9

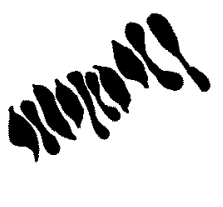

Figs. 1-9. 1, Vernonia cinerea, metaphase I showing 9 bivalents. 2, Ageratum conyzoides, tetraploid, showing 20 bivalents at diakinesis. 3 , Ageratum conyzoides, diploid, showing 10 bivalents at metaphase I. 4, Brachycome iberidifolia, metaphase I showing 9 bivalents. Figs. 5-8. Blumea lacera. 5, metaphase I (5II+1I). 6, metaphase I $(1 \mathrm{VII}+2 \mathrm{II})$. 7 , metaphase I $(1 \mathrm{IV}+1 \mathrm{III}+2 \mathrm{II})$. 8 , anaphase I showing bridges. 9, Blumea laciniata. metaphase I showing 10 bivalents. 
average height of 6 inches. Meiosis was regular. Pollen mother cells showed 9 bivalents at metaphase I (Fig. 4).

\section{Blumea lacera DC.}

This species is quite common in this area and was cytologically interesting. Meiosis was irregular showing structural heterozygosity. A count of $2 \mathfrak{n}=11$ was made (Fig. 5). Eleven chromosomes showed different types of chromosome associations (Figs. 6,7) ranging from univalents to associations of 11 chromosomes. Chromosome associations at metaphase $\mathrm{I}$ is shown in Table 2. Anaphase I and anaphase II mainly showed bridges and fragments almost invariably (Fig. 8).

Table 2. Chromosome association at diakinesis and metaphase I in taxa showing relatively more irregular meiosis

\begin{tabular}{|c|c|c|c|c|c|c|c|c|c|c|}
\hline \multirow{2}{*}{ Species } & & & \multicolumn{8}{|c|}{ Chromosome associations } \\
\hline & & & I & II & III & IV & V & VI & VII-XI & $\mathrm{BChr}$ \\
\hline Blumea lacera & $(2 n=11)$ & $\begin{array}{l}\text { Range } \\
\text { Mean }\end{array}$ & $\begin{array}{r}0-2 \\
.23\end{array}$ & $\begin{array}{r}0-3 \\
.82\end{array}$ & $\begin{array}{r}0-3 \\
.91\end{array}$ & $\begin{array}{r}0-1 \\
.18\end{array}$ & $\begin{array}{r}0-1 \\
.32\end{array}$ & $\begin{array}{r}0-1 \\
.18\end{array}$ & $\begin{array}{r}0-1 \\
.32\end{array}$ & - \\
\hline Vicoa indica & $(2 n=27)$ & $\begin{array}{l}\text { Range } \\
\text { Mean }\end{array}$ & $\begin{array}{l}1-6 \\
2.93\end{array}$ & $\begin{array}{c}1-5 \\
2.80\end{array}$ & $\begin{array}{l}4-8 \\
6.18\end{array}$ & - & - & - & - & - \\
\hline $\begin{array}{l}\text { Chrysanthemum } \\
\text { coronarium }\end{array}$ & $(2 n=18)$ & $\begin{array}{l}\text { Range } \\
\text { Mean }\end{array}$ & $\begin{array}{r}0-1 \\
.04\end{array}$ & $\begin{array}{l}3-7 \\
4.30\end{array}$ & $\begin{array}{r}0-1 \\
.04\end{array}$ & $\begin{array}{l}0-3 \\
1.18\end{array}$ & I & $\begin{array}{r}0-2 \\
.61\end{array}$ & - & - \\
\hline $\begin{array}{l}\text { Dimorphotheca } \\
\text { pluvialis }\end{array}$ & $(2 \mathrm{n}=17+1 \mathrm{~B})$ & $\begin{array}{l}\text { Range } \\
\text { Mean }\end{array}$ & $\begin{array}{l}0-3 \\
1.20\end{array}$ & $\begin{array}{c}6-8 \\
7.70\end{array}$ & $\begin{array}{r}0-1 \\
.20\end{array}$ & - & - & $\overline{-}$ & - & $\begin{array}{r}0-1 \\
.50\end{array}$ \\
\hline
\end{tabular}

Blumea laciniata (Roxb.) DC.

This is another species of Blumea, which is quite common in this area and looks very much like $B$. lacera. Meiosis was normal and 10 bivalents were observed at metaphase I (Fig. 9). The chromosome distribution at anaphase I and anaphase II was also normal.

Gnaphalium purpureum Linn.

A very common species during months of March-April in dry habitats. Pollen mother cells showed 9 bivalents at diakinesis I (Fig. 10). Detailed meiosis could not be worked out.

Vicoa indica (Willd.) DC.

It is a small herb flowering mainly through March-May in dry habitats. Two chromosome races namely : diploid and triploid were found. Diploids were more vigorous and more common. They showed 9 bivalents which disjoined $9: 9$ at anaphase I (Fig. 11). Triploids showed irregular meiosis and gave a clear count of $2 n=27$ at anaphase I (Fig. 12). Trivalents were very frequent at metaphase I and diakinesis (Fig. 13). Chromosome association at diakinesis and metaphase $\mathrm{I}$ is given in Table 2. Laggards and bridges were also commonly found at anaphase I and anaphase II (Figs. 14-16). The frequency 
of laggards and bridge: is given in Table 3 . The morphological characters of 2 races are given in Tabie 4 .

Helichysum bracteatum Wilk1.

It is an ornamental flowering, plant. Meiosis was normal. Fifteen bivalents were observed at diakinesis (Fig. 17).

Jacobaea vestita (Wall.) O. Kuntz.

It is found as a common weed. The meiosis was found in be normal. Both at diakinesis and meta phase I, 9 bivalents were invariably observed (Fig. 18).

Coreopsis coronata Hook.

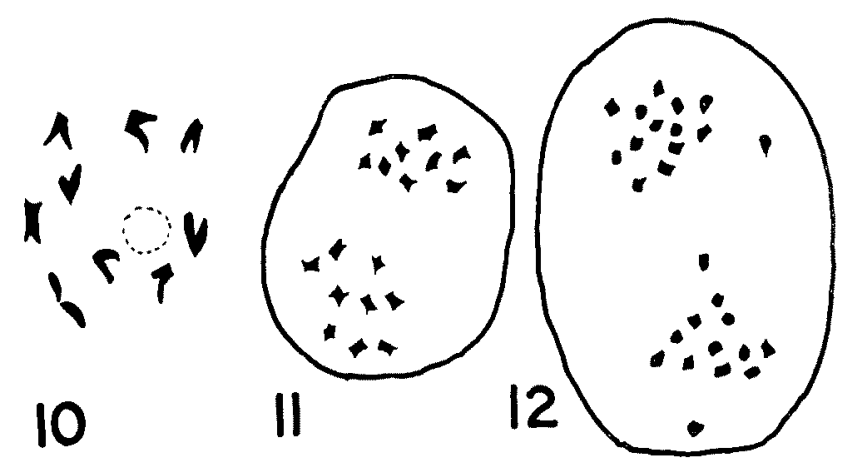

This is a rare species in this area. Only sporadic plants were seen. Meiosis was normal and 10 bivalents were normally observed at diakinesis and metaphase I. At anaphase I there was regular distribution of $10: 10$ chromosomes to each pole (Fig. 19).

Eclipta alba Hassk.

It is a very common herb found everywhere. It also shows some range of morphological variations. At diakinesis, 11 bivalents were observed (Fig. 20).

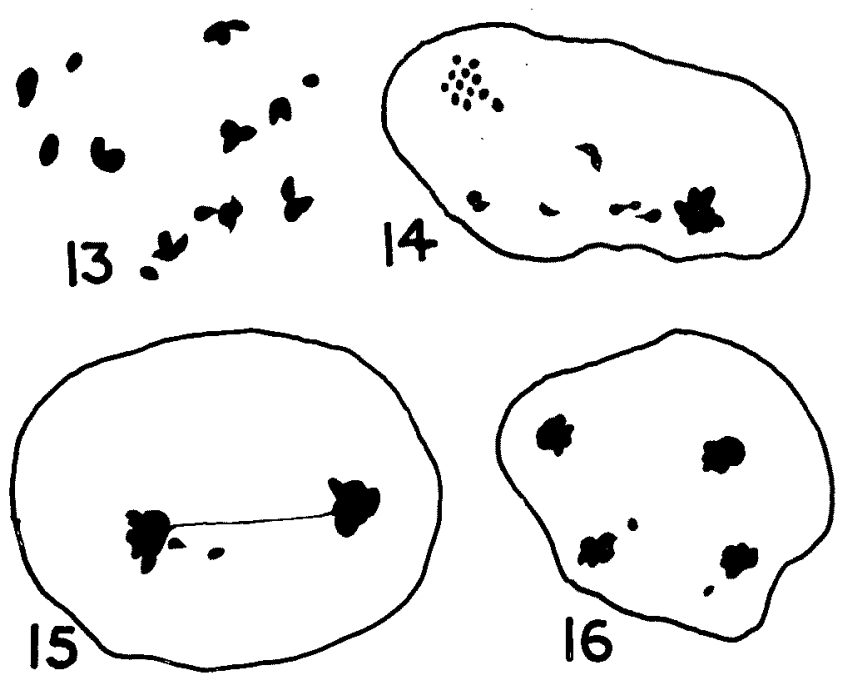

Figs. 10-16. 10, Gnaphalium purpureum, diakinesis showing 9 bivalents. 11-16. Vicoa indica. 11, diploid at anaphase I. showing 9 chromosomes at each pole. 12-16, triploid, fig. 12 showing 27 chromosomes at anaphase I. 13, diakinesis $(6 I I I+3 I I+3 I), 14$, showing lagging chromosomes at anaphase I. 15, showing a bridge at anaphase I and fig. 16 showing lagging chromosomes at anaphase II.

Meiosis was normal.

Tridax procumbens Linn.

A very common weed growing everywhere in large numbers. All the 
plants examined were tetraploids, showing 18 bivalents (Fig. 21). Due to cytomixis cells with aberrant chromosome numbers were also common (Fig. 22). Chrysanthemum coronarium Linn.

This species was found as a weed in the spring flowering beds. The chromosomes were much bigger in size than in other taxa studied. Meiosis

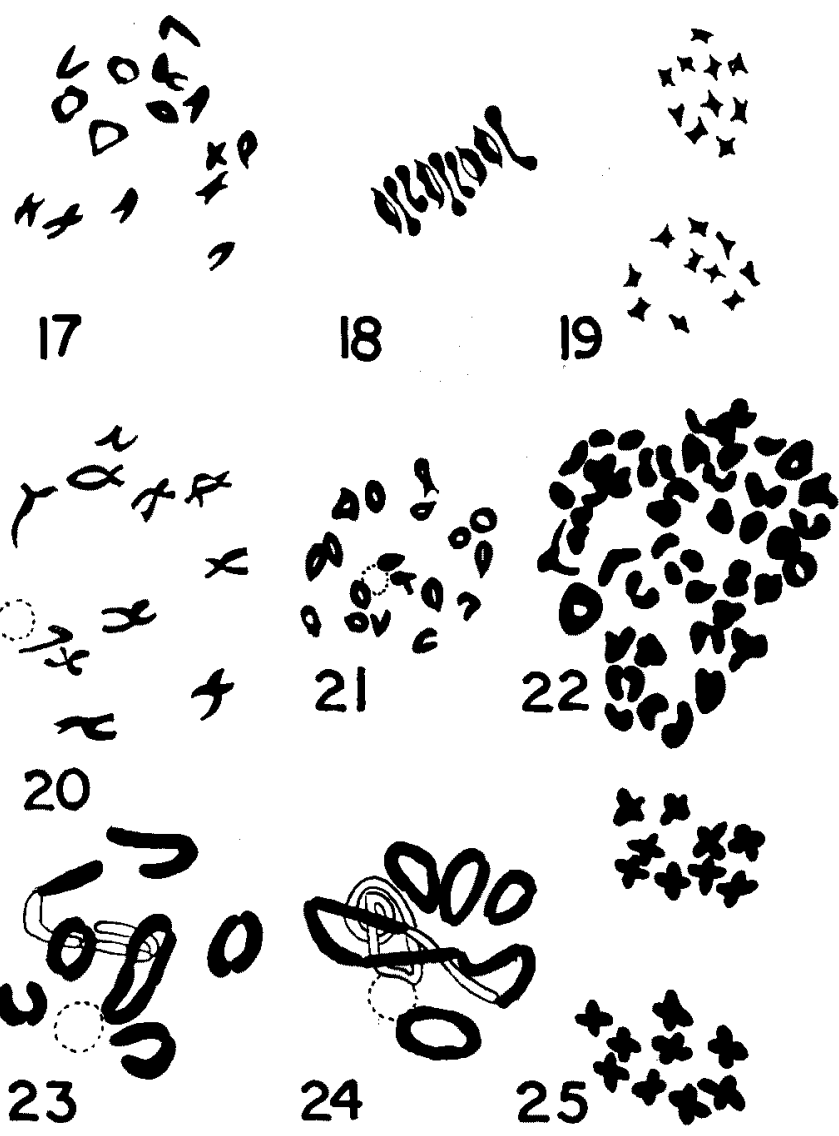

Figs. 17-20. 17, Helichrysum bracteatum, diakinesis showing 15 bivalents. 18, Jacobaea vestita, metaphase I showing 9 bivalents. 19, Coreopsis coronata, anaphase I with 10 chromosomes at each pole. 20, Eclipta alba, diakinesis showing 11 bivalents. Figs. 21, 22. Tridax procumbens. 21, showing 18 bivalents at diakinesis; 22, showing an aberrant cell with large number of chromosomes. Figs. 23-25, Chrysanthemum coronarium. 23, diakinesis $(2 \mathrm{IV}+5 \mathrm{II})$. 24, diakinesis (1VI+ IIV $+4 I I) .25$, anaphase I showing 9 chromosomes at each pole.

was irregular. Multivalents, particularly quadrivalents and hexavalents were common (Fig. 23, 24). Most common chromosome association was $4^{\mathrm{II}}+1^{\mathrm{IV}}$ $+1^{\mathrm{vI}}$, which was found in $47.8 \%$ of the cells studied. Analysis of chromosome association in this plant is given in Table 2. At anaphase I (Fig. 25) and anaphase II, distribution of chromosome was regular and no lagging chromosomes or bridges were observed. Pollen fertility was normal suggesting uniform alternate disjunction. Since only one healthy plant was available, normal chromosome behaviour in this plant could not be worked out.

Calendula officinalis Linn.

It is a cultivated ornamental plant. Meiosis was regular. At diakinesis and metaphase I, 16 bivalents were observed (Fig. 26).

Dimorphotheca pulvialis Moench.

It is a cultivated ornamental. The diploid chromosome number was earlier reported to be $2 n=18$ (Bilquez 1951). A chromosome variant was 
studied in this species in detail and showed $2 n=17+1 B$ (Fig. 27). One trivalent could be rarely observed (Fig. 28), the most common configuration bing $8^{\mathrm{II}}+1^{\mathrm{I}}+1 \mathrm{~B}$. The analysis of chromosome association at metaphase $\mathrm{I}$ is given in Table 2 . The distribution of lagging chromosomes at anaphase I and anaphase II is shown in Table 3. At anaphase I and anaphase II irregularities like lagging of univalent and/or B chromosome (Fig. 2931) were observed. $8: 9$ distribution of chromosomes at anaphase I resulted in the formation of 4 nuclei, 2 with 9 chromosomes each and the other 2 with 8 chromosomes each. Variations like formation of micronuclei, inclusion or exclusion of $\mathrm{B}$ chromosome etc. were also found.

Sonchus asper Vill.

It is a common weed found in the months of March-May. At metaphase I, 9 bi-

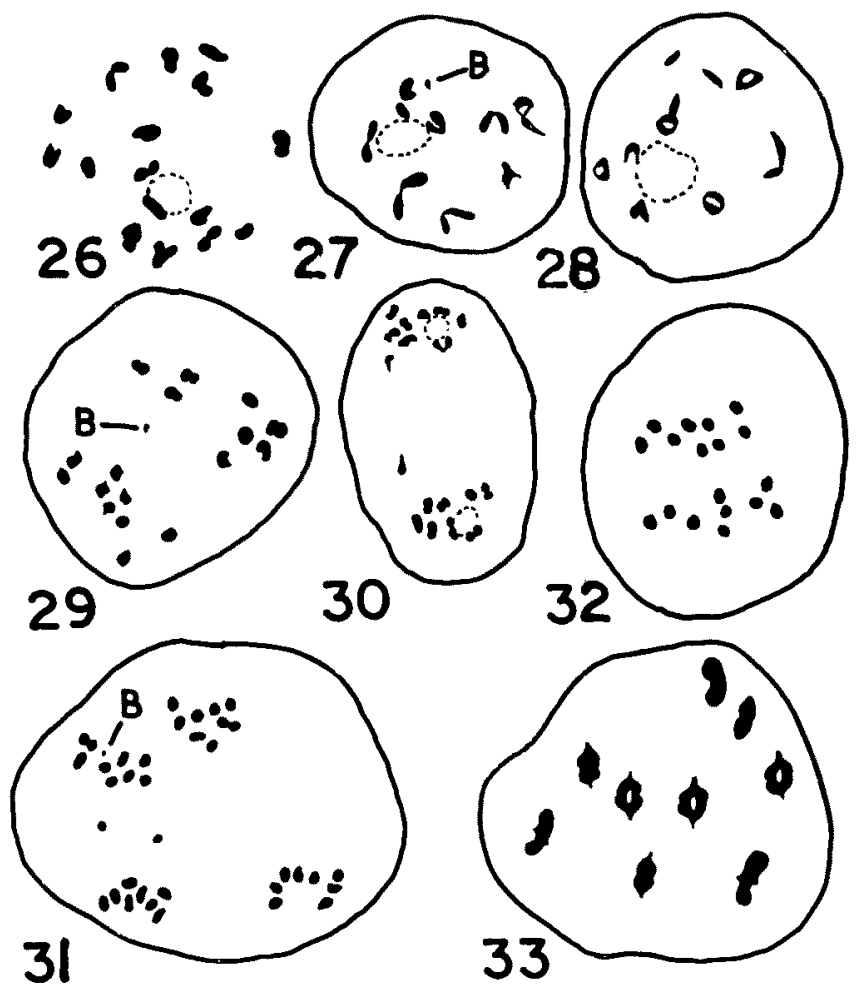

Fig. 26. Calendula officinalis, diakineis showing 16 bivalents. Figs. 27-31. Dimorphotheca pluvialis. 27, showing $8 I I+1 I+1 B$ at diakinesis. 28 , showing $1 \mathrm{III}+6 \mathrm{II}+2 \mathrm{I}$. 29 , with B chromosome lagging. 30 , with univalent dividing at anaphase I. 31, anaphase II showing 2 laggards and 8 chromosomes in Figs. 32, 33. 32, Sonchus asper, anaphase I with 9 chromosomes at each pole. 33, Launaea nudicaulis, metaphase I showing 9 bivalents.

Table 3. Frequency of Jagging chromosomes and bridges at anaphase I and anaphase II in meiotically irregular species

\begin{tabular}{|c|c|c|c|c|c|c|c|c|c|}
\hline \multirow{2}{*}{ Species } & & \multirow{2}{*}{$\begin{array}{c}\% \text { of cells } \\
\text { without } \\
\text { laggards }\end{array}$} & \multicolumn{7}{|c|}{$\%$ of cells with laggards and bridges } \\
\hline & & & 1 & 2 & 3 & 4 & 5 & $1 \mathrm{br}$ & $1 \mathrm{br}+1 \mathrm{~B}$ \\
\hline $\begin{array}{l}\text { Vicoa indica } \\
2 \mathrm{n}=27)\end{array}$ & $\begin{array}{l}\text { anaphase I } \\
\text { anaphase II }\end{array}$ & $\begin{array}{l}52.2 \\
74.1\end{array}$ & 32.2 & $\begin{array}{r}8.9 \\
25.9\end{array}$ & 3.3 & 1.1 & 1.1 & 1.1 & - \\
\hline $\begin{array}{c}\text { Dimorphotheca } \\
\text { pluvialis }\end{array}$ & anaphase I & 72.4 & $\begin{array}{r}12.2 \\
4.9^{*}\end{array}$ & 4.9 & $\mid \begin{array}{l}2.4 \\
2.4 * *\end{array}$ & - & - & 2.4 & - \\
\hline$(2 \mathrm{n}=17+1 \mathrm{~B})$ & anaphase II & 75.9 & 6.9 & - & $13.9 * *$ & - & - & - & 3.4 \\
\hline
\end{tabular}

* Lagging chromosome is a $B$ chromosome.

** One of the 3 laggards is a $B$ chromosome. 
valents were regularly formed. They showed regular 9:9 disjunction at anaphase I (Fig. 32).

\section{Launaea nudicaulis Less}

Two distinct ecotypes, one completely prostrate with small flowering axis and the other erect with long flowering axis. The prostrate ecotype was found in the adverse ecological conditions, while the erect one is found in favorable habitats. In both the cases at anaphase I, 9 bivalents were observed (Fig. 33). Meiosis was regular. The characters of 2 ecotypes are given in Table 4. Table 4. Morphological characters of the ecotypes and cytotypes within species (All measurements in $\mathrm{cm}$ )

\begin{tabular}{|c|c|c|c|c|c|c|}
\hline \multirow{2}{*}{ Taxa } & \multicolumn{2}{|c|}{ Plant size } & \multicolumn{2}{|c|}{ Leaf size $(\mathrm{L} \times \mathrm{B})$} & \multicolumn{2}{|c|}{ Head size (radius) } \\
\hline & Range & Mean & Range & Mean & Range & Mean \\
\hline $\begin{array}{l}\text { Vernonia cinerea } \\
\text { Collection no. } 114(2 \mathrm{n}=18)\end{array}$ & $9.4-18.6$ & 12.5 & $\begin{array}{r}1.5-4.5 \\
\times 0.4-2.5\end{array}$ & $\begin{array}{l}2.9 \times \\
1.5\end{array}$ & $0.4-0.3$ & 0.7 \\
\hline Collection no. $124(2 \mathrm{n}=18)$ & $45.5-63.4$ & 54.8 & $\begin{array}{r}0.7-2.5 \\
\times 0.2-1.0\end{array}$ & $\begin{array}{l}1.4 \times \\
0.5\end{array}$ & $0.3-0.5$ & 0.4 \\
\hline $\begin{array}{l}\text { Ageratum conyzoides } \\
\text { Collection no. } 115(2 \mathrm{n}=20)\end{array}$ & $45.6-65.2$ & 55.6 & $\begin{array}{r}2.8-4.6 \\
\times 1.7-3.1\end{array}$ & $\begin{array}{l}3.5 \times \\
2.4\end{array}$ & $0.4-0.8$ & 0.6 \\
\hline Collection no. $106(2 \mathrm{n}=40)$ & $8.4-38.6$ & 15.6 & $\begin{array}{r}1.2-4.0 \\
\times 0.6-3.0\end{array}$ & $\begin{array}{l}1.5 \times \\
1.0\end{array}$ & $0.2-0.4$ & 0.3 \\
\hline $\begin{array}{l}\text { Vicoa indica } \\
\text { Collection no. } 116(2 \mathrm{n}=18)\end{array}$ & $8.2-21.5$ & 14.5 & $\begin{array}{r}1.8-5.2 \\
\times 0.4-0.7\end{array}$ & $\begin{array}{l}3.5 \times \\
0.5\end{array}$ & $0.9-0.5$ & 0.7 \\
\hline Collection no. $116(2 \mathrm{n}=27)$ & $7.3-12.5$ & 9.4 & $\begin{array}{r}1.8-2.6 \\
\times 0.3-0.5\end{array}$ & $\begin{array}{l}2.1 \times \\
0.4\end{array}$ & $0.4-0.6$ & 0.5 \\
\hline $\begin{array}{l}\text { Launaea nudicaulis } \\
\text { Collection no. } 111(2 \mathrm{n}=18)\end{array}$ & $30.4-55.8$ & 43.5 & $\begin{array}{r}6.0-11.2 \\
\times 0.8-2.8\end{array}$ & $\begin{array}{l}9.2 \times \\
2.1\end{array}$ & $0.9=1.4$ & 1.2 \\
\hline Collection no. $134(2 \mathrm{n}=18)$ & $5.6-14.5$ & 8.5 & $\begin{array}{r}2.1-7.5 \\
\times 0.3-1.0\end{array}$ & $\begin{array}{l}5.1 \times \\
0.7\end{array}$ & $0.6-1.0$ & 0.9 \\
\hline
\end{tabular}

\section{Discussion}

Of the total number of 17 species studied, in case of Vernonia cinerea, Ageratum conyzoides, Eclipta alba, Tridax procumbens, Calendula offcinalis, Sonchus asper and Launaea nudicaulis, observations in the present study confirmed the previous reports. The rest of the 10 species showed either new counts or other interesting features. Ecotypic differentiation was reported in case of Vernonia cinerea and Launaea nudicaulis. Chromosome races were reported in Ageratum conyzoides and Vicoa indica.

In the tribe Astereae, base numbers 4,5,6,7,8,9 and 11 were known. In Brachycome iberidifolia $\mathrm{n}=9$ was observed. This species has been studied here for the first time.

In the tribe Inuleae, genera: Blumea $(\mathrm{x}=$ ?), Gnaphalium $(\mathrm{x}=9)$, Vicoa $(\mathrm{x}=9)$, Helichrysum $(\mathrm{x}=15)$ and Jacobaea $(\mathrm{x}=9)$ were studied. The previous reports of $\mathrm{x}=11$ in the genus Blumea has to be revised in the light of the 
present study. B. lacera gave a count of $2 n=11$ in the present study, which suggests that $2 \mathrm{n}=22$ reported earlier must have been a derived polyploid taxon. The 11 chromosomes in the present study were found to be involved in complex translocations so that in some cases as many as all the 11 chromosomes were involved in single chromosome association. B. laciniata gave a count of $\mathrm{x}=10$. If it is not a polyploid, it would suggest an additional base number of $x=10$. On the other hand if $2 n=20,22$ are polyploid counts, the base number in this genus would be $\mathrm{x}=5$ or $\mathrm{x}=6$, as suggested by the present study in B. lacera.

Earlier reports on the genus Gnaphalium gave $\mathrm{x}=7$. In the present study $\mathrm{n}=9$ in $G$. purpureum was the first count in this species and gave a new count in the genus. Vicoa indica and Jacobaea vestita, were studied for the first time and both gave a count of $n=9$. Chromosome races were found in case of Vicoa indica. The high frequency of trivalents in the triploid race suggests an autotriploid nature and should have been derived from a cross of diploid and tetraploid in nature. No tetraploids were however found. The triploid race is rare and shows high degree of pollen sterility. A study of the root system showed very strong long root, which might be responsible for providing means of vegetative propagation. Jacobaea vestita $(\mathbf{n}=9)$ is the first report in this genus.

In the tribe Heliantheae, 3 genera namely Coreopsis $(\mathrm{x}=10) ;$ Eclipta $(\mathrm{x}=11)$ and Tridax $(\mathrm{x}=9)$ were studied. Studies on Eclipta alba and Tridax procumbens confirmed previous reports. Coreopsis coronata was studied for the first time and gave new base number for the genus. Previously known base numbers in this genus are 12,13 and 14 .

In the tribe Anthemideae, only one taxon-Chrysanthemum coronarium was studied, which confirmed previous report $(\mathbf{n}=9)$. The plant studied was an aberrant plant and showed $4^{\mathrm{II}}+1^{\mathrm{IV}}+1^{\mathrm{VI}}$ as the most common configuration. It indicates presence of as many as 3 translocations. Other 2 plants belonging to this species, which were the only plants found, were not as vigorous and could not be cytologically examined due to poor growth.

In the tribe Calenduleae, Calendula officinalis $(\mathrm{n}=16)$ and Dimorphotheca pluvialis were studied. The latter gave a count of $2 n=17+1 B$. Previous count of $2 \mathrm{n}=18$ by Bilquez (1951) in this species suggests it to be hypodiploid. $\mathrm{B}$ chromosome however did not show association with the univalent. However presence of low frequency of trivalents suggests, on the other hand, that it may be a hyperdiploid with $2 \mathrm{n}=16$ being the original chromosome number.

In tribe Cichorieae, studies on Sonchus asper and Launaea nudicaulis confirmed the previous reports.

\section{Summary}

Twenty one taxa belonging to 16 genera and 17 species of the family Compositae found locally in Gorakhpur were cytologically examined. Ecotypes 
were reported in 2 species. Chromosome races were recorded in 2 other species. Six species were studied for the first time. New chromosome counts were given for 2 other species. Structural heterozygosity was reported in 2 species.

Acknowledgments: The author is grateful to Prof. K. S. Bhargava, Head of the Botany Department, Gorakhpur University, Gorakhpur for providing necessary facilities.

\section{References}

Bentham, G. 1873. Notes on the classification, history and geographic distribution of Compositae. Jour. Linn. Soc. Bot. London 13: 335-578.

*Bilquez, D. 1951. In Darlington and Wylie: "Chromosome Altas of Flowering Plants". p. 266.

*Ganesan, D. 1939. Jour. Genet. 83: 493.

*Grant, V. 1953. Evolution 7: 51.

Hooker, J. D. 1882. Flora of British India. Vol. 3. L. Reeve \& Co., London.

Hutchinson, J. 1959. Families of Flowering Plants. Oxford Clarendon.

*Ishikawa, M. 1916. Bot. Mag. Tokyo 30: 404.

Kaul, M. L.H. 1964. Chromosome number in some medicinal Compositae. Proc. Ind. Acad. Sci. 59: 72-77.

-1965. Cytogenetics and ecology of three medicinal plants. Ph. D. Abs. Banaras Hindu University, Varanasi. 1-15.

Khoshoo, T. N. and Sobti, S. N. 1958. Cytology of Indian species of Artemesia. Nature 181 (4612): 853-854.

Kishore, H. 1951. A note on chromosome number of some plants. Ind. Jour. Genet. 11: 217.

Mehra, P. N., Gill, B. S., Mehta, J. K. and Sidhu, S. S. 1965. Cytological investigations on the Indian Compositae I. North-Indian taxa. Carylogia 18: 35-68.

*Mitra, J. 1947. Jour. Ind. Bot. Soc. 36: 105.

*Negodi, G. 1936a. Riv. Biol. 20: 15.

Ornduff, R., Raven, P.H., Khyos, D. W. and Kruckberg, A. R. 1963. Chromosome numbers in Compositae. III. Senecioneae. Amer. J. Bot. 50: 131-139.

Raghavan, T.S. and Venkatasubban. 1941. Contribution to the cytology of Tridax procumbens Linn. Proc. Ind. Acad. Sci. 13: 85-105.

Raven, P.H., Solbrig, O.T., Khyos, D.W. and Snow, R. 1960. Chromosome numbers in Compositae I. Astereae. Amer. J. Bot. 47: 124-132.

Rendle, A. B. 1959. The classification of flowering plants. Vol. 2. Cambridge Univ. Press. London.

Shetty, V. A. 1964. Chromosome numbers in some flowering plants. Curr. Sci. 33: 58-59.

*Shimotomai, N. and Hara, K. 1935. Bot. and Zool. Tokyo 3: 1759.

Singh, B. 1951. Chromosome numbers in some flowering plants. Curr. Sci. 20: 105.

Stebbins, G. L., Jenkin, J. A. and Walters, M.S. 1953. Chromosome and phylogeny in the Compositae, tribe Cichorieae. Univ. Calif. Publ. Bot. 26: 401-430.

*Tongiorgi, E. 1942. Nuovo G. bot. ital. 49: 242.

Turner, B. L. 1959. Meiotic chromosome counts for 12 species of Texas Compositae. Brittonia 11: 173-177.

-and Johnston, M. C. 1961. Chromosome numbers in Compositae. III. Brittonia. 13: 64-69.

- and Lewis, W. H. 1965. Chromosome numbers in the Compositae. IX. African species. Jour. South Afr. Bot. 31: 207-217.

*Weddle, C. 1941. Proc. Amer. Soc. Hort. Sci. 39: 393.

* From Darlington and Wylie: "Chromosome atlas of flowering plants." 